\title{
PENGEMBANGAN MEDIA VIDEO PEMBELAJARAN MERAKIT PERSONAL KOMPUTER PADA SISWA KELAS X TEKNIK KOMPUTER DAN JARINGAN DI SMK SWASTA TRI KARYA
}

\author{
Abdiel Ginting ${ }^{1}$, Harun Sitompul ${ }^{2}$, Keysar Panjaitan ${ }^{3}$ \\ ${ }^{1}$ SMK Swasta Tri Karya, ${ }^{2,3}$ Pascasarjana Universitas Negeri Medan \\ abdielsniper@gmail.com ${ }^{1}$
}

\begin{abstract}
Abstrak: Penelitian ini bertujuan untuk Untuk menghasilkan media video pembelajaran perakitan personal komputer yang berkualitas dan layak dijadikan acuan bagi siswa, mudah dipelajari, dipahami dan dapat digunakan secara individual, Untuk mengetahui keefektifan penggunaan media video pembelajaran pada mata pelajaran Produktif Teknik Komputer dan Jaringan pada materi perakitan komputer. Jenis penelitian ini adalah penelitian pengembangan yang menggunakan model pengembangan produk Borg and Gall yang dipadu dengan model desain pembelajaran dari Dick and Carey. Hasil penelitian menunjukkan: uji ahli materi berada pada kualifikasi sangat baik (92,27\%), uji ahli desain pembelajaran berada pada kualifikasi sangat baik (93,53\%), uji ahli media pembelajaran berada pada kualifikasi sangat baik (92,67 \%), uji coba perorangan berada pada kualifikasi sangat baik (89,58\%), uji coba kelompok kecil berada pada kualifikasi sangat baik (91,11\%), dan uji coba pada lapangan terbatas berada pada kualifikasi sangat baik (97,28\%). Produk akhir dari pengembangan video ini dilanjutkan dengan uji keefektifan produk. Penelitian dilakukan pada peserta didik kelas X. Metode yang digunakan dalam penelitian ini adalah metode kuasi eksperimen. Sampel penelitian sebanyak 70 peserta didik yang terdiri dari 35 peserta didik sebagai kelas eksperimen yang diajar menggunakan video, dan 35 peserta didik lainnya sebagai kelas kontrol yang diajarakan tanpa menggunakan media video. Hasil pengujian hipotesis menunjukkan bahwa terdapat perbedaan yang signifikan antara hasil belajar peserta didik yang dibelajarkan menggunakan video dengan hasil belajar peserta didik yang dibelajarkan tanpa menggunakan video. Hal ini ditunjukkan berdasarkan hasil pengolahan data diperoleh $t_{\text {hitung }}=8,77>t_{\text {tabel }}=1,99$, dengan $d k=\left(n_{1}+n_{2}-2\right)$ pada taraf signifikansi $\alpha$ 0,05. Dari hasil tersebut dapat disimpulkan bahwa hasil belajar peserta didik yang dibelajarkan dengan menggunakan video sebesar $83,66 \%$ lebih tinggi dari pada peserta didik yang dibelajarkan tanpa menggunakan video sebesar $69,46 \%$.
\end{abstract}

Kata Kunci: pengembangan media video pembelajaran, media pembelajaran, teknik komputer dan jaringan, hasil belajar merakit komputer

\begin{abstract}
This study aims to produce video learning media of personal computer assembly that is qualified and deserves to be used as a reference for students, easy to learn, understood and can be used individually, To know effectiveness of using video learning media on subjects Productive Computer Engineering And Network on computer assembly materials. This type of research is a development research using the Borg and Gall product development model combined with the instructional design model from Dick and Carey. The result of the research shows that: the material expert test is in very good qualification (92.27\%), the test of the learning design is in very good qualification (93,53\%), (92.67\%), individual trials are in excellent qualifications (89.58\%), small group trials are in excellent qualifications (91.11\%), and Trials on limited field are in excellent qualification (97.28\%). The end product of this video development is followed by product effectiveness test. The research was conducted on class $X$ students. The method used in this research is quasi-experimental method. The sample of the study were 70 students consisting of 35 students as experimental class taught using video, and 35 other students as control class which was taught without using video media. The result of hypothesis testing shows that there is a significant difference between the learners' learning result which is learned by using the video with the learning result of the learners which is learned without using video. This is shown based on the result of data processing obtained tcont $=8,77 \alpha$ ttable $=$ 1,99, with $d k=(n 1+n 2-2)$ at significance level $\alpha 0,05$. From these results can be concluded that the learning outcomes of learners who were taught by using the video of $83.66 \%$ higher than the learners who were taught without using video of $69.46 \%$.
\end{abstract}

Keywords : development of learning video media, instructional media, computer and networking techniques, learning result of assembling computer 


\section{PENDAHULUAN}

Perkembangan IPTEK dewasa ini telah membawa perubahan pesat dalam aspek kehidupan manusia, perkembangan tersebut telah mengubah paradigma manusia dalam mencari dan mendapatkan informasi semakin mudah. Pekerjaan yang semula dilakukan manusia secara manual kini dapat digantikan dengan mesin. Hal ini menuntut manusia untuk berpikir lebih maju dalam segala hal agar tidak dianggap tertinggal. Salah satu bidang yang mendapatkan dampak cukup berarti dalam perkembangan IPTEK adalah bidang pendidikan, dimana pada dasarnya pendidikan merupakan suatu proses komunikasi dan informasi antara guru kepada siswa yang berisi informasi-informasi pendidikan, yang memiliki unsur-unsur pendidik sebagai sumber informasi, media sebagai sarana penyajian ide, gagasan dan materi pendidikan serta siswa itu sendiri. Perkembangan teknologi informasi dan komunikasi yang saat ini semakin pesat di dunia pendidikan menuntut peningkatkan kinerja baik dari segi keefektifan dan efesiensi.

Dengan meningkat dan berkembangnya teknologi informasi dibutuhkan suatu sistem pendidikan yang berkualitas baik dari segi mutu materi pendidikan, pengajaran, pengujian serta sarana dan prasarana pendidikan. Rusman dkk (2011 :93) mengungkapkan bahwa di era kemajuan teknologi pada masa modern saat ini yaitu dengan ditemukannya komputer maka penggunaan TIK dalam kegiatan pembelajaran harus dikembangkan dalam lembaga pendidikan untuk memenuhi tuntutan global pendidikan dalam mempersiapkan sumberdaya manusia yang berkualitas global.

Perkembangan TIK juga mengubah paradigma masyarakat dalam mencari dan mendapatkan informasi yang tidak lagi hanya terbatas pada media cetak, radio dan televisi, tetapi juga menjadikan teknologi jaringan global, internet sebagai salah satu sumber informasi utama, sehingga memberikan kemudahan bagi siswa/siswi dalam memperoleh informasi.

Menurut Rusman (2011, 1) , proses pembelajaran merupakan suatu sistem yang terdiri atas berbagai komponen yang saling berhubungan antara satu sama lainnya. Komponen tersebut meliputi : tujuan, materi, metode, dan evaluasi. Komponen yang saling mendukung tersebut menimbulkan proses komunikasi melalui proses penyampaian pesan dari sumber pesan melalui saluran atau media tertentu kepada penerima pesan.

Salah satu upaya pembangunan pendidikan adalah peningkatan kualitas proses pembelajaran. Sistem pendidikan disebut bermutu dari segi proses adalah jika proses belajar mengajar berlangsung secara efektif dan siswa mengalami proses pembelajaran yang bermakna ditunjang oleh berbagai jenis sumber belajar yang dicapai oleh pembelajar.

Undang-Undang Sisdiknas No. 20 Tahun 2003 mengemukakan seiring dengan perubahan paradigm pembelajaran, maka keberhasilan kegiatan belajar mengajar di kelas tidak hanya ditentukan oleh faktor pendidik, melainkan sangat dipengaruhi oleh keaktifan peserta didik dengan pendidik sebagai sumber belajar pada lingkungan belajar. Dengan demikian, peserta didik seharusnya tidak belajar dari pendidik saja, namun mampu belajar dari berbagai sumber yang tersedia di lingkungannya.

Menurut Kunandar (2011 : 22), saat ini peran guru sebagai knowledge agent telah bergeser menjadi learning agent yang mendorong, membantu dan mengarahkan peserta didik untuk mengalami proses pembelajaran sesuai dengan minat, bakat, potensi, perkembangan fisik dan psikologinya. Dalam proses kegiatan belajar mengajar, guru diharapkan dapat menciptakan kegiatan situasi kegiatan belajar mengajar yang lebih banyak melibatkan aktifitas siswa, sedangkan siswa itu sendiri hendaknya dapat memotivasi dirinya sendiri untuk aktif dalam kegiatan belajar mengajar.

Media berbasis komputer merupakan kombinasi antara teks, grafik, animasi,suara, dan video. Penggabungan ini merupakan suatu kesatuan yang secara bersama-sama menampilkan informasi, pesan, dan isi pelajaran. Multimedia bertujuan untuk menyajikan informasi dalam bentuk yang menyenangkan, menarik, mudah dimengerti, dan jelas. Informasi akan mudah dimengerti karena sebanyak mungkin indera, terutama telinga dan mata, digunakan untuk menyerap informasi itu (Arsyad,2010 : 170-172).

Dari beberapa pendapat di atas, maka dapat disimpulkan bahwa multimedia sangat bermanfaat sebagai bahan referensi pembelajaran. Multimedia memiliki sifat yang sederhana, jelas dan mudah dimengerti sehingga materi yang disampaikan dapat cepat 
diserap melalui indra penglihatan, pendengaran dan melalui visualisasi gambar sehingga dapat merangsang siswa untuk melakukan praktek dengan tahapan langkah yang jelas. Untuk itu perlu dikembangkan suatu media pembelajaran yang mampu mengatasi keadaaan tersebut. Media yang dikembangkan harus sesuai dengan kebutuhan yang diperlukan sekolah khususnya dalam pembelajaran Merakit Personal Komputer serta mampu mengatasi keragaman kemampuan kognitif tiap siswa, hal ini berarti siswa dapat mengendalikan media tersebut menurut kemampuannya masing-masing. Dalam hal ini dibutuhkan media yang menampilkan secara rinci tahapan langkah perakitan personal komputer yang dapat dipraktikan langsung oleh siswa, sehingga mempermudah pemahaman siswa. sehingga mampu menimbulkan umpan balik dan motivasi untuk belajar.

Dalam Kurikulum Tingkat Satuan Pendidikan, disebutkan salah satu standar kompetensi untuk kompetensi keahlian teknik komputer jaringan dengan mata pelajaran Produktif Teknik Komputer dan Jaringan yaitu : Merakit Pesonal Komputer. Mengacu pada standar kompetensi di atas dapat disimpulkan bahwa siswa dituntut untuk mampu merakit komputer dengan tahapan prosedur yang telah di tentukan. Peneliti melihat, bahwa pengembangan video untuk mata pelajaran Produktif Teknik Komputer dan Jaringan merupakan alternatif yang tepat dalam proses belajar mengajar. Pemanfaatan teknologi informasi dalam bentuk video yang dilengkapi dengan fitur-fitur gambar yang menarik, iringan lagu yang menarik, serta seluruh unsur model yang kompeten, dapat membuat suasana belajar mengajar berlangsung secara menarik dan tercipta proses pembelajaran yang tidak terkesan monoton dan membosankan, serta mudah dipahami. Selain itu juga membantu daya serap siswa terhadap materi yang disampaikan, dan dapat diaplikasikan langsung tanpa harus menunggu pembelajaran yang disampaikan atau diawasi oleh guru.

Penggunaan media pembelajaran dalam proses pembelajaran sangat penting, media pembelajaran sangat membantu memecahkan permasalahan belajar dan dapat mempermudah siswa memahami materi pelajaran. Dalam hal ini guru dituntut untuk kreatif. Seperti yang disampaikan Sadiman (2010 : 17), penggunaan media pendidikan secara tepat dan bervariasi dapat mengatasi sikap pasif anak didik. Sesuai dengan pendapat di atas, maka guru dituntut untuk dapat mengembangkan dan menggunakan media pembelajaran. Kemampuan guru dalam menggunakan media pembelajaran memungkinkan guru mengatur berbagai teknik belajar yang tepat sehingga siswa memperoleh manfaat yang sebesar-besarnya dari media tersebut, dan membantu siswa lebih cepat memahami materi pelajaran yang disajikan guru sesuai dengan tujuan yang diharapkan.

Senada dengan pendapat Hamalik (dalam Arsyad 2014 : 19) Mengemukakan bahwa pemakaian media pembelajaran dalam proses belajar mengajar dapat membangkitkan keinginan dan minat yang baru, membangkitkan motivasi dan rangsangan keinginan dan minat yang baru, membangkitkan motivasi dan rangsangan kegiatan belajar, dan bahkan membawa pengaruh - pengaruh psikologis terhadap siswa.

Penggunaan media pembelajaran seringkali menjadi masalah yang dihadapi oleh guru, disekolah tidak memiliki fasilitas media yang cukup, kemudian kelemahan guru dalam menciptakan dan menggunakan media. Menurut Arsyad (Arsyad 2014 :2) menyatakan bahwa guru dituntut agar mampu menggunakan alatalat yang dapat disediakan oleh sekolah, dan tidak tertutup kemungkinan bahwa alat-alat tersebut sesuai dengan perkembangan dan tuntutan zaman. Dari pernyataan tersebut tersirat bahwa pengajaran harus memiliki pengetahuan dan pemahaman yang cukup mengenai media pembelajaran. Apalagi pada masa sekarang ini, teknologi informasi sudah mengalami perkembangan yang sangat cepat sehingga diharapkan guru juga mampu berinovasi menciptakan suatu pembelajaran yang menarik dengan pemanfaatan media yang didukung dengan strategi pembelajaran yang tepat sehingga proses pembelajaran bisa efektif.

Berdasarkan pengamatan awal yang penulis lakukan pada beberapa guru, guru membutuhkan media pembelajaran lebih efektif. Sebelumnya guru hanya menggunakan media buku, guru sebagai tutor, dan belum banyak guru mempunyai media pembelajaran. Sementara itu pembelajaran yang berlangsung di sekolah masih dilaksanakan dengan konvensional yaitu pembelajaran yang berpusat pada guru, yaitu guru menyampaikan materi dengan ceramah kemudian guru melakukan demonstrasi. 
Berdasarkan hasil temuan data pada mata pelajaran Produktif Teknik Komputer dan Jaringan, menunjukkan antara lain : (1) penerapan media pembelajaran yang masih kurang melalui pemanfaatan sumber belajar. (2) belum maksimal pemanfaatan media pembelajaran dalam proses belajar mengajar. (3) hasil belajar siswa masih rendah. Selain kendala di atas juga ditemukan adanya permasalahan lain berkaitan dengan proses pembelajaran . Dari hasil wawancara khusus dengan guru mata pelajaran Produktif Teknik Komputer dan Jaringan pada bulan februari 2016 dapat di simpulkan bahwa selama ini mata pelajaran tersebut dilaksanakan dengan ceramah kemudian praktik yang di simulasikan oleh guru terlebih dahulu, kemudian bersamasama oleh 35 siswa. Mengingat materi perakitan komputer ini merupakan materi yang sangat penting karena merupakan dasar dalam kompetensi keahlian teknik komputer dan jaringan, hal ini tentu saja menyebabkan kurang tersampaikannya tujuan dalam proses pembelajaran.

Media berbasis komputer merupakan kombinasi antara teks, grafik,animasi,suara, dan video. Penggabungan ini merupakan suatu kesatuan yang secara bersama-sama menampilkan informasi, pesan, dan isi pelajaran. Multimedia bertujuan untuk menyajikan informasi dalam bentuk yang menyenangkan, menarik, mudah dimengerti, dan jelas. Informasi akan mudah dimengerti karena sebanyak mungkin indera, terutama telinga dan mata, digunakan untuk menyerap informasi itu (Arsyad,2010 : 170-172).

Dari beberapa pendapat di atas, maka dapat disimpulkan bahwa multimedia sangat bermanfaat sebagai bahan referensi pembelajaran. Multimedia memiliki sifat yang sederhana, jelas dan mudah dimengerti sehingga materi yang disampaikan dapat cepat diserap melalui indra penglihatan, pendengaran dan melalui visualisasi gambar sehingga dapat merangsang siswa untuk melakukan praktek dengan tahapan langkah yang jelas. Untuk itu perlu dikembangkan suatu media pembelajaran yang mampu mengatasi keadaaan tersebut. Media yang dikembangkan harus sesuai dengan kebutuhan yang diperlukan sekolah khususnya dalam pembelajaran Merakit Personal Komputer serta mampu mengatasi keragaman kemampuan kognitif tiap siswa, hal ini berarti siswa dapat mengendalikan media tersebut menurut kemampuannya masing-masing. Dalam hal ini dibutuhkan media yang menampilkan secara rinci tahapan langkah perakitan personal komputer yang dapat dipraktikan langsung oleh siswa, sehingga mempermudah pemahaman siswa. sehingga mampu menimbulkan umpan balik dan motivasi untuk belajar.

Dalam Kurikulum Tingkat Satuan Pendidikan, disebutkan salah satu standar kompetensi untuk kompetensi keahlian teknik komputer jaringan dengan mata pelajaran Produktif Teknik Komputer dan Jaringan yaitu : Merakit Pesonal Komputer. Mengacu pada standar kompetensi di atas dapat disimpulkan bahwa siswa dituntut untuk mampu merakit komputer dengan tahapan prosedur yang telah di tentukan.

Peneliti melihat, bahwa pengembangan video untuk mata pelajaran Produktif Teknik Komputer dan Jaringan merupakan alternatif yang tepat dalam proses belajar mengajar. Pemanfaatan teknologi informasi dalam bentuk video yang dilengkapi dengan fitur-fitur gambar yang menarik, iringan lagu yang menarik, serta seluruh unsur model yang kompeten, dapat membuat suasana belajar mengajar berlangsung secara menarik dan tercipta proses pembelajaran yang tidak terkesan monoton dan membosankan, serta mudah dipahami. Selain itu juga membantu daya serap siswa terhadap materi yang disampaikan, dan dapat diaplikasikan langsung tanpa harus menunggu pembelajaran yang disampaikan atau diawasi oleh guru.

\section{METODE PENELITIAN}

Dalam penelitian dan pengembangan ini model yang akan dikembangkan mengacu kepada Research and Development (R\&D) dari model Borg \& Gell (1983) yang memiliki tujuan untuk mengembangkan dan memvalidasai produk dengan perencanaan pembelajaran dalam pengembangan video pembelajaran Dick \& Carey (2009).

Borg \& Gall (1983) mengemukakan penelitian pengembangan adalah penelitian yang berorientasi untuk mengembangkan dan memvalidasi produk-produk yang digunakan dalam pendidikan. Menurut Sugiyono (2009) penelitian dan pengembangan adalah metode penelitian yang digunakan untuk menghasilkan produk tertentu dan menguji keefektifan produk tersebut. Senada dengan pendapat Syaodih 
(2010) penelitian pengembangan adalah suatu proses atau langkah-langkah untuk mengembangkan suatu produk baru atau menyempurnakan produk yang telah ada. Produk tersebut dapat berupa benda atau perangkat keras (Hardware) seperti buku, modul, alat bantu pembelajaran atau perangkat lunak (Software) seperti program computer, pembelajaran dikelas model-model pendidikan.

Skema tersebut dirujuk dari tha major steps in the $R$ \& $D$ cycle Borg \& Gall. Peneliti merujuk hingga ke prosedur kesembilan dari tahapan tersebut diatas pada tahap kesepuluh peneliti tidak mencakup ke Dissemination and Implementation dikarenakan keterbatasan waktu dan lain sebagainya. Melalui prosedur di atas dapat diwujudkan dan dikembangkan kedalam bentuk perencanaan teknis sasaran dan jenis kegiatan yang akan peneliti lakukan tiap tahapnya.

Adapun langkah-langkah dari tahapan pengembangan sebagai berikut:

1. Melakukan penelitian pendahuluan yang meliputi :

2. Mendesain media video pembelajaran

3. Pengumpulan bahan yang meliputi

4. Review dan uji coba produk

5. Uji keefektifan produk

Prosedur pengembangan media video pembelajaran ini dilakukan dengan prosedur sebagai berikut :

1. Mengembangkan desain pembelajaran. Adapun langkah pengembangan desain pembelajarannya adalah sebagai berikut: (a) identifikasi kebutuhan instruksional dan menulis standar kompetensi mata pelajaran, (b) melakukan analisis pembelajaran, (c) mengidentifikasi karakteristik dan perilaku awal peserta didik, (d) menulis kompetensi dasar serta indikatornya, (e) menulis tes acuan patokan, (f) menyusun strategi pembelajaran, (g) mengembangkan bahan pembelajaran, (h) mendesain evaluasi formatif.

2. Pembuatan desain video pembelajaran yang akan dikembangkan dalam multimedia pembelajaran interktif, yang meliputi: (a) pembuatan flowchart, (b) pembuatan storyboard, (c) pembuatan naskah.

3. Pengumpulan bahan, yang meliputi: (a) pembuatan dan pengumpulan gambar (image), merekam suara, membuat animasi-animasi yang akan digunakan dalam materi maupun simulasi, (b) perekaman dan pengumpulan audio.

4. Melakukan validasi produk dari ahli media dan ahli materi

5. Melakukan revisi tahap pertama hasil dari validasi ahli media, dan ahli materi

6. Melakukan revisi produk tahap awal

7. Melakukan uji coba perorangan dengan siswa calon pengguna media pembelajaran;.

8. Melakukan revisi tahap ke 2

9. Melakukan uji coba lapangan

10. Melakukan revisi akhir yang dikembangkan dalam produk video pembelajaran dalam bentuk bentuk media pembelajaran.

Uji coba dimaksudkan untuk mengumpulkan data dalam rangka evaluasi formatif yang dijadikan dasar dalam menetapkan apakah produk tersebut telah benar-benar layak digunakan dan menarik. Kegiatan yang dilakukan antara lain:

1. Desain Uji Coba

2. Subjek Uji Coba

3. Pelaksanaan Uji Coba

Bentuk instrument penilaian menggunakan format Rating Scale terhadap produk yang dikembangkan yang berisikan tentang pertanyaan-pertanyaan yang berhubungan dengan kondisi atau keadaan media video pembelajaran tersebut, dengan skala penilaian "1" sangat kurang baik/sangat kurang layak/sangat kurang menarik/sangat kurang sesuai/sangat kurang tepat/sangat kurang jelas, criteria penilaian " 2 " kurang baik/kurang layak/kurang menarik/kurang sesuai/kurang tepat/kurang jelas, criteria penilaian "3" cukup baik/cukup layak/cukup menarik/cukup sesuai/cukup tepat/cukup jelas, criteria penilaian "4" baik/layak/menarik/mudah/sesuai/tepat/jelas, criteria penilaian "5" sangat baik/sangat layak/sangat menarik/sangat mudah/sangat sesuai/sangat tepat/sangat jelas.

Tabel 1. Pedoman dan kriteria penilaian

\begin{tabular}{|c|c|c|}
\hline Presentase & Kriteria & Nilai \\
\hline $81 \% \leq \mathrm{x} \leq 100 \%$ & Sangat Baik & A \\
\hline $61 \% \leq \mathrm{x}<80 \%$ & Baik & B \\
\hline $41 \% \leq \mathrm{x}<60 \%$ & Cukup & $\mathrm{C}$ \\
\hline $21 \% \leq \mathrm{x}<40 \%$ & Kurang Baik & $\mathrm{D}$ \\
\hline $0 \% \leq \mathrm{x}<20 \%$ & $\begin{array}{c}\text { Sangat Kurang } \\
\text { Baik }\end{array}$ & $\mathrm{E}$ \\
\hline
\end{tabular}




\section{HASIL DAN PEMBAHASAN}

Proses pelaksanaan pengembangan media video pembelajaran merakit personal komputer ini dilakukan secara bertahap. Pada tahap awal penelitian dan pengembangan ini adalah menetapkan mata pelajaran yang akan dikembangkan. Tahap selanjutnya adalah melakukan penelitian pendahuluan sesuai dengan silabus. Penelitian ini bertujuan untuk memperoleh data kebutuhan apa yang diperlukan oleh guru dan peserta didik dalam proses belajar mengajar, selain itu penelitian ini bertujuan untuk memperoleh data dan bagaimana konsep media yang akan dibuat dengan metode observasi dan wawancara. Proses pertama dalam kegiatan pengembangan ini adalah melakukan analisis kebutuhan awal dengan cara menebar angket kepada 35 peserta didik, kemudian dilakukan hal yang sama pada bulan Februari dengan menebar angket kepada 6 guru komputer dengan metode mengurai definisi dari media video pembelajaran pada angket agar responden memiliki gambaran tentang pertanyaan dalam angket yang disampaikan. Hasil penelusuran angket yang telah disebar ditemukan bahwa $100 \%$ dari peserta didik menyatakan kebutuhan media video pembelajaranl merakit personal komputer pada kelas X Teknik Komputer Dan Jaringan

Data analisis kebutuhan tersebut ditampilkan pada Tabel 2 berikut ini :

Tabel 2. Data Analisis Kebutuhan

\begin{tabular}{|c|c|c|c|c|c|c|}
\hline \multirow[b]{2}{*}{ No } & \multirow{2}{*}{$\begin{array}{l}\text { Jenis } \\
\text { Informasi }\end{array}$} & \multirow[b]{2}{*}{ Jawaban } & \multicolumn{3}{|c|}{ Frekuensi } & \multirow{2}{*}{$\begin{array}{l}\text { Persentase } \\
\quad(\%)\end{array}$} \\
\hline & & & Guru & $\begin{array}{l}\text { Peserta } \\
\text { Didik }\end{array}$ & Jlh. & \\
\hline 1 & $\begin{array}{l}\text { Telah mengenal atau tidak mengenal } \\
\text { media video pembelajaran merakit } \\
\text { personal komputer. }\end{array}$ & $\begin{array}{c}\text { Ya } \\
\text { Tidak }\end{array}$ & 2 & $\begin{array}{l}2 \\
33\end{array}$ & 4 & $\begin{array}{l}9,76 \% \\
90,24 \%\end{array}$ \\
\hline 2 & $\begin{array}{l}\text { Memerlukan atau tidak memerlukan } \\
\text { media video pembelajaran merakit } \\
\text { personal komputer. }\end{array}$ & $\begin{array}{c}\text { Ya } \\
\text { Tidak }\end{array}$ & $\begin{array}{l}6 \\
0\end{array}$ & $\begin{array}{l}35 \\
0\end{array}$ & $\begin{array}{l}41 \\
0\end{array}$ & $\begin{array}{l}100 \% \\
0 \%\end{array}$ \\
\hline 3 & $\begin{array}{l}\text { Menggunakan atau tidak } \\
\text { menggunakan media dalam } \\
\text { pembelajaran }\end{array}$ & $\begin{array}{c}\text { Ya } \\
\text { Tidak }\end{array}$ & 2 & 35 & 39 & $\begin{array}{l}4,9 \% \\
95,1 \%\end{array}$ \\
\hline 4 & $\begin{array}{l}\text { Tersedia atau tidak tersedia media } \\
\text { pembelajaran di sekolah }\end{array}$ & $\begin{array}{c}\text { Ya } \\
\text { Tidak }\end{array}$ & $\begin{array}{l}5 \\
1\end{array}$ & $\begin{array}{c}35 \\
0\end{array}$ & $\begin{array}{c}40 \\
1\end{array}$ & $\begin{array}{c}97,6 \% \\
2,4 \%\end{array}$ \\
\hline 5 & $\begin{array}{l}\text { Mampu menggunakan media video } \\
\text { pembelajaran }\end{array}$ & $\begin{array}{c}\text { Ya } \\
\text { Tidak }\end{array}$ & $\begin{array}{l}4 \\
2\end{array}$ & $\begin{array}{c}30 \\
5\end{array}$ & $\begin{array}{c}34 \\
7\end{array}$ & $\begin{array}{l}82,93 \% \\
17,07 \%\end{array}$ \\
\hline
\end{tabular}

Berdasarkan hasil angket analisis kebutuhan yang disebarkan kepada siswa dan guru kesimpulan sebagai berikut :

a. sebagian besar siswa maupun guru $(90,24 \%)$ menyatakan belum mengenal media video pembelajaran merakit personal komputer hanya sebagian kecil $(9,76 \%)$ guru dan siswa yang menyatakan telah mengenal media video pembelajaran tersebut.

b. $100 \%$ dari jumlah guru dan siswa menyatakan memerlukan media video pembelajaran merakit personal komputer pada proses pembelajaran.

c. Sebagian besar $(95,1 \%)$ dosen menyatakan tidak menggunakan media video pembelajaran dalam proses pembelajaran dan seluruh siswa $100 \%$ menyatakan tidak pernah menggunakan media pembelajaran tersebut.

d. Sebagian besar guru maupun peserta didik (97,6\%) menyatakan bahwa media pembelajaran tersedia di sekolah dan hanya sebagian kecil $(2,4 \%)$ dari mereka menyatakan sebaliknya.

e. Sebagian besar guru maupun peserta didik $(82,93 \%)$ menyatakan mampu menggunakan media video pembelajaran dan hanya sebagian kecil $(17,07 \%)$ dari dari mereka menyatakan tidak mampu menggunakan media video pembelajaran.

Berdasarkan hasil analisis kabutuhan dapat disimpulkan bahwa pengembangan media video pembelajaran memang sangat dibutuhkan oleh siswa dan guru dalam proses pembelajaran. Hasil wawancara secara lisan kepada guru mata pelajaran, menyatakan bahwa mereka 
membutuhkan media video pembelajaran untuk menunjang proses pembelajaran karena mereka mengakui sulit mendapatkan media video pembelajaran yang efektif untuk menyampaikan materi pembelajaran. Setelah memperoleh serangkaian proses pengembangan, maka langkah selanjutnya adalah mendesain dan mengembangkan media video pembelajaran dengan menggunakan program. Produk awal dari media video pembelajaran yang dikembangkan adalah media video pembelajaran merakit personal komputer untuk kelas $\mathrm{X}$ semester satu dengan fokus pada pembelajaran melakukan instalasi komponen PC.

Berdasarkan validasi produk melalui serangkaian uji coba dan revisi yang telah dilakukan, maka video pembelajan merakit personal komputer pada mata pelajaran Produktif Teknik Komputer dan Jaringan telah memiliki status valid. Uji coba dilakukan dengan enam tahapan yaitu: (a) validasi ahli materi, (b) validasi ahli desain pembelajaran, (c) validasi ahli media pembelajaran, (d) uji coba perorangan, (e) uji coba kelompok kecil dan, (f) uji coba lapangan terbatas.

Penilaian dilakukan terhadap produk dimaksudkan untuk mendapatkan informasi yang akan digunakan untuk meningkatkan kelayakan media video pembelajaran merakit personal komputer pada. Hasil validasi berupa skor penilaian terhadap indikator penilaian video pembelajaran merakit personal komputer dari aspek kelayakan isi video pembelajaran dinyatakan valid dengan persentase skor $92 \%$ dengan kriteria "sangat baik". Kemudian pada aspek penyajian persentase skornya $93,75 \%$ dengan kriteria "sangat baik". Dan aspek kebahasaan persentase skor penilaiannya 93,33\% dengan kriteria "sangat baik". Serta dari aspek kegrafikan persentase skor penilaiannya $90,00 \%$ dengan kriteria "sangat baik". Untuk uraian penilaian sertiap indikator dapat dilihat pada Tabel 3 berikut ini.

Tabel 3. Skor Penilaian dan Tanggapan Instrumen Validasi Penelitian Tentang kualitas Materi Pembelajaran Oleh Ahli Materi

\begin{tabular}{|c|c|c|c|c|c|c|c|}
\hline \multirow[b]{2}{*}{ No } & \multirow[b]{2}{*}{ Aspek } & \multirow[b]{2}{*}{ Indikator Penilaian } & \multicolumn{2}{|c|}{ Responden } & \multirow{2}{*}{$\begin{array}{c}\text { Jumla } \\
\mathrm{h} \\
\text { Skor }\end{array}$} & \multirow{2}{*}{$\begin{array}{l}\text { Rata- } \\
\text { Rata }\end{array}$} & \multirow[b]{2}{*}{ Kriteria } \\
\hline & & & 1 & 2 & & & \\
\hline 1 & \multirow{6}{*}{$\begin{array}{l}\text { Kelaya } \\
\text { kan Isi }\end{array}$} & $\begin{array}{l}\text { Kejelasan Tujuan } \\
\text { Pembelajaran }\end{array}$ & 5 & 5 & 10 & $100,00 \%$ & Sangat Baik \\
\hline 2 & & Ketepatan Cakupan Materi & 4 & 5 & 9 & $90,00 \%$ & Sangat Baik \\
\hline 3 & & Kebenaran Konsep & 4 & 4 & 8 & $80,00 \%$ & Baik \\
\hline 4 & & $\begin{array}{l}\text { Kedalaman Materi } \\
\text { Pembelajaran }\end{array}$ & 4 & 5 & 9 & $90,00 \%$ & Sangat Baik \\
\hline 5 & & $\begin{array}{l}\text { Kesesuaian Dengan } \\
\text { Kurikulum }\end{array}$ & 5 & 5 & 10 & $100,00 \%$ & Sangat Baik \\
\hline \multirow[t]{3}{*}{6} & & $\begin{array}{l}\text { Ketepatan Urutan Materi } \\
\text { Pembelajaran }\end{array}$ & 5 & 4 & 9 & $90,00 \%$ & Sangat Baik \\
\hline & & Jumlah & 27 & 28 & 55 & \multirow{2}{*}{$92 \%$} & \multirow{2}{*}{ Sangat Baik } \\
\hline & & Rata-Rata & 4,5 & 4,7 & 9,2 & & \\
\hline 7 & \multirow{8}{*}{$\begin{array}{l}\text { Penyaji } \\
\text { an }\end{array}$} & Kualitas Pendahuluan & 5 & 5 & 10 & $100,00 \%$ & Sangat Baik \\
\hline 8 & & Kualitas Penyajian Materi & 4 & 5 & 9 & $90,00 \%$ & Sangat Baik \\
\hline 9 & & $\begin{array}{l}\text { Keterlibatan Dan Peran Siswa } \\
\text { Dalam Aktivitas Belajar }\end{array}$ & 5 & 5 & 10 & $100,00 \%$ & Sangat Baik \\
\hline 10 & & Kualitas Umpan Balik & 4 & 5 & 9 & $90,00 \%$ & Sangat Baik \\
\hline 11 & & Waktu Penyajian & 5 & 4 & 9 & $90,00 \%$ & Sangat Baik \\
\hline 12 & & $\begin{array}{l}\text { Ketercernaan Materi Dan } \\
\text { Pemaparan Yang Logis }\end{array}$ & 4 & 4 & 8 & $80,00 \%$ & Baik \\
\hline 13 & & Penggunaan Bahasa & 5 & 5 & 10 & $100,00 \%$ & Sangat Baik \\
\hline \multirow[t]{3}{*}{14} & & $\begin{array}{l}\text { Kemudahan Pemahaman } \\
\text { Bahasa }\end{array}$ & 5 & 5 & 10 & $100,00 \%$ & Sangat Baik \\
\hline & & Jumlah & 37 & 38 & 75 & \multirow{2}{*}{$93,75 \%$} & \multirow{2}{*}{ Sangat Baik } \\
\hline & & Rata-Rata & 4,6 & 4,8 & 9,38 & & \\
\hline
\end{tabular}




\begin{tabular}{|c|c|c|c|c|c|c|c|}
\hline 15 & \multirow{3}{*}{$\begin{array}{l}\text { Kebaha } \\
\text { saan }\end{array}$} & $\begin{array}{l}\text { Ketercernaan Materi Dan } \\
\text { Pemaparan Yang Logis }\end{array}$ & 5 & 5 & 10 & $100,00 \%$ & Sangat Baik \\
\hline 16 & & Penggunaaan Bahasa & 4 & 5 & 9 & $90,00 \%$ & Sangat Baik \\
\hline 17 & & $\begin{array}{l}\text { Kemudahan Pemahaman } \\
\text { Bahasa }\end{array}$ & 4 & 5 & 9 & $90,00 \%$ & Sangat Baik \\
\hline & & Jumlah & 13 & 15 & 28 & \multirow{2}{*}{$93,33 \%$} & \multirow{2}{*}{ Sangat Baik } \\
\hline & & Rata-Rata & 4,3 & 5,0 & 9,3 & & \\
\hline 18 & $\begin{array}{c}\text { Kegrafi } \\
\text { kan }\end{array}$ & $\begin{array}{l}\text { Kualitas Tampilan Dan } \\
\text { Ilustrasi }\end{array}$ & 4 & 5 & 9 & $90,00 \%$ & Sangat Baik \\
\hline \multicolumn{3}{|r|}{ Rata-Rata } & 4 & 5 & 9 & \multirow{2}{*}{$90,00 \%$} & \multirow{2}{*}{ Sangat Baik } \\
\hline & & Jumlah & 4 & 5 & 9 & & \\
\hline
\end{tabular}

Penilaian yang dilakukan terhadap produk yang dikembangkan dimaksudkan untuk mendapatkan informasi yang akan digunakan untuk meningkatkan kualitas produk yang dikembangkan. Ahli desain pembelajaran menvalidasi produk pada aspek-aspek kelayakan isi yang terdiri dari kualitas desain pembelajaran, aspek penyajian yang terdiri dari kualitas desain informasi, aspek kegrafikan yang terdiri dari kualitas presentasi dan aspek keaktifan yang terdiri dari kualitas desain informasi ditinjau dari penilaian ahli materi. Hasil berupa skor penilaian terhadap media video pembelajaran merakit personal komputer dari aspek kelayakan isi produk tersebut dinyatakan valid dengan persentase skor 95\% dengan kriteria "sangat baik". Kemudian pada aspek penyajian persentase skornya 92,73\% dengan kriteria "sangat baik". Dan pada aspek kebahasaan persentase skornya 92,86\% dengan kriteri "sangat baik'. Sehingga dapat disimpilkan bahwa produk yang dikembangkan dapat dikatakan valid dengan skor persentase 93,53\% dengan kriteria "sangat baik". Untuk uraian penilaian setiap indikator dapat dilihat pada Tabel 4 berikut ini.

Tabel 4. Skor Penilaian Validasi Penelitian Tentang Kualitas Materi Pembelajaran Sistem Penyampaian Oleh Ahli Desain Pembelajaran

\begin{tabular}{|c|c|c|c|c|c|c|c|}
\hline \multirow{2}{*}{ No } & \multirow{2}{*}{ Aspek } & \multirow{2}{*}{ Indikator Penilaian } & \multicolumn{2}{|c|}{ Responden } & \multirow{2}{*}{$\begin{array}{c}\text { Jumlah } \\
\text { Skor }\end{array}$} & \multirow{2}{*}{ Rata-Rata } & \multirow{2}{*}{ Kriteria } \\
\hline & & & 1 & 2 & & & \\
\hline 1 & \multirow{4}{*}{$\begin{array}{l}\text { Kelayakan } \\
\text { Isi }\end{array}$} & \multirow{4}{*}{$\begin{array}{l}\text { Ketepatan Pemilihan } \\
\text { Topik } \\
\text { Kesesuaian Materi } \\
\text { Dengan Indikator } \\
\text { Pembelajaran } \\
\text { Pemberian Latihan } \\
\text { Konsistensi Tes Dengan } \\
\text { Indikator Pembelajaran }\end{array}$} & 5 & 5 & 10 & $100,00 \%$ & $\begin{array}{c}\text { Sangat } \\
\text { Baik }\end{array}$ \\
\hline 2 & & & 5 & 5 & 10 & $100,00 \%$ & $\begin{array}{c}\text { Sangat } \\
\text { Baik }\end{array}$ \\
\hline 3 & & & 4 & 4 & 8 & $80,00 \%$ & Baik \\
\hline 4 & & & 5 & 5 & 10 & $100,00 \%$ & $\begin{array}{c}\text { Sangat } \\
\text { Baik }\end{array}$ \\
\hline & & Jumlah & 19 & 19 & 38 & \multirow{2}{*}{$95 \%$} & \multirow{2}{*}{$\begin{array}{c}\text { Sangat } \\
\text { Baik }\end{array}$} \\
\hline & & Rata-Rata & 4,75 & 4,8 & 9,50 & & \\
\hline 5 & \multirow{6}{*}{ Penyajian } & \multirow{6}{*}{$\begin{array}{l}\text { Pemberian Motivasi } \\
\text { Kejelasan Uraian Materi } \\
\text { Kejelasan Contoh Yang } \\
\text { Diberikan } \\
\text { Penggunaan Informasi } \\
\text { Baru } \\
\text { Umpan Balik Terhadap } \\
\text { Hasil Tes Siswa } \\
\text { Pembabakan/Sekuensial }\end{array}$} & 4 & 5 & 9 & $90,00 \%$ & $\begin{array}{c}\text { Sangat } \\
\text { Baik }\end{array}$ \\
\hline 6 & & & 5 & 5 & 10 & $100,00 \%$ & $\begin{array}{c}\text { Sangat } \\
\text { Baik }\end{array}$ \\
\hline 7 & & & 5 & 5 & 10 & $100,00 \%$ & $\begin{array}{c}\text { Sangat } \\
\text { Baik }\end{array}$ \\
\hline 8 & & & 4 & 4 & 8 & $80,00 \%$ & Baik \\
\hline 9 & & & 5 & 5 & 10 & $100,00 \%$ & $\begin{array}{c}\text { Sangat } \\
\text { Baik }\end{array}$ \\
\hline 10 & & & 5 & 4 & 9 & $90,00 \%$ & Sangat \\
\hline
\end{tabular}




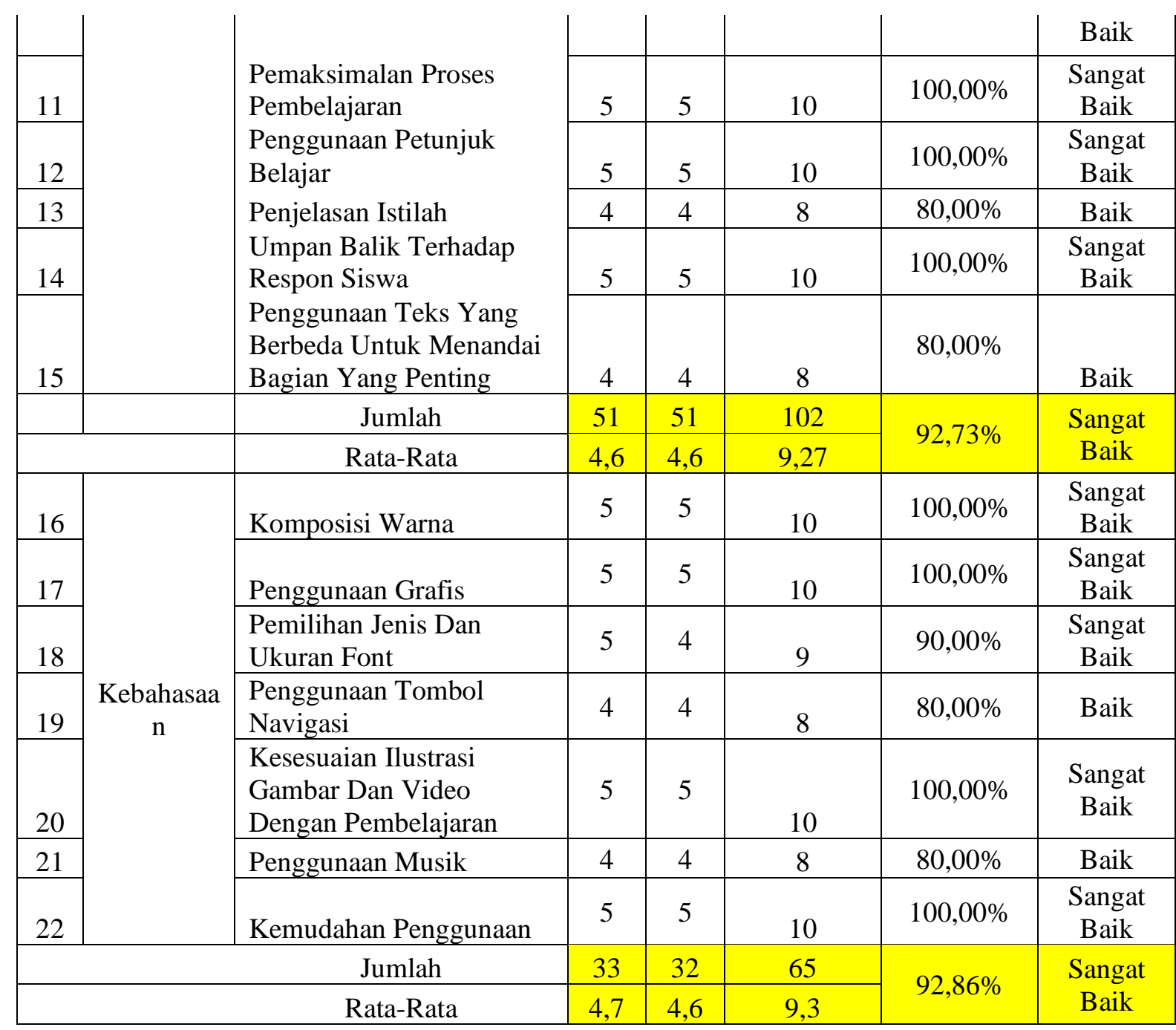

Penilaian dilakukan untuk mendapatkan informasi yang akan digunakan untuk meningkatkan kelayakan media video pembelajaran merakit personal komputer, khususnya merakit personal komputer untuk peserta didik. Hasil validasi berupa skor penilaian terhadap komponen media video pembelajaran merakit personal komputer, meliputi aspek tampilan video pembelajaran dan aspek pemrograman. Hasil validasi berupa skor penilaian terhadap indikator penilaian video pembelajaran berbasis pendekatan dari aspek pemograman dikatakan valid dengan persentase skor $92 \%$ dengan kriteria "sangat baik", kemudian pada aspek kualitas teks dan tampilan juga dikatakan valid dengan persentase skor 93,33\% dengan kriteria "sangat baik". Sehingga dengan demikian dapat dikatakan bahwa produk yang dikembangkan layak digunakan berdasarkan persentase skor 92,65\% dengan kriteria "sangat baik". Untuk lebih rincinya dapat dilihat pada Tabel 5 berikut ini.

Tabel 5. Skor Penilaian dan Tanggapan Instrumen Validasi Penelitian Tentang Kualitas Desain Informasi, Desain Interaksi dan Desain Presentasi Untuk Ahli Media Pembelajaran

\begin{tabular}{|c|c|c|c|c|c|c|c|}
\hline \multirow{2}{*}{ No } & \multirow{2}{*}{ Aspek } & \multirow{2}{*}{ Indikator Penilaian } & \multicolumn{2}{|c|}{ Responden } & \multirow{2}{*}{$\begin{array}{c}\text { Jumlah } \\
\text { Skor }\end{array}$} & \multirow{2}{*}{$\begin{array}{l}\text { Rata- } \\
\text { Rata }\end{array}$} & \multirow{2}{*}{ Kriteria } \\
\hline & & & 1 & 2 & & & \\
\hline 1 & \multirow{3}{*}{$\begin{array}{l}\text { Pemogr } \\
\text { aman }\end{array}$} & Perintah Eksekusi & 5 & 5 & 10 & $100,00 \%$ & Sangat Baik \\
\hline 2 & & Konsistensi Dengan Program & 4 & 5 & 9 & $90,00 \%$ & Sangat Baik \\
\hline 3 & & Efisiensi Sistem & 5 & 4 & 9 & $90,00 \%$ & Sangat Baik \\
\hline
\end{tabular}




\begin{tabular}{|c|c|c|c|c|c|c|c|}
\hline 4 & & Ketepatan Display & 5 & 4 & 9 & $90,00 \%$ & Sangat Baik \\
\hline 5 & & $\begin{array}{l}\text { Konsistensi Antar Bagian } \\
\text { Pelajaran }\end{array}$ & 4 & 5 & 9 & $90,00 \%$ & Sangat Baik \\
\hline 6 & & Modifikasi Yang Mudah & 4 & 5 & 9 & $90,00 \%$ & Sangat Baik \\
\hline & & Jumlah & 27 & 28 & 55 & \multirow{2}{*}{$92 \%$} & \multirow{2}{*}{ Sangat Baik } \\
\hline & & Rata-Rata & 4,5 & 4,7 & 9,17 & & \\
\hline 7 & \multirow{6}{*}{$\begin{array}{c}\text { Kualita } \\
\text { s Teks } \\
\text { Dan } \\
\text { Tampil } \\
\text { an }\end{array}$} & Keindahan Tampilan Layar & 5 & 5 & 10 & $100,00 \%$ & Sangat Baik \\
\hline 8 & & Kemudahan Membaca Teks & 5 & 5 & 10 & $100,00 \%$ & Sangat Baik \\
\hline 9 & & $\begin{array}{l}\text { Kualitas Video,Gambar Dan } \\
\text { Animasi }\end{array}$ & 5 & 5 & 10 & $100,00 \%$ & Sangat Baik \\
\hline 10 & & Komposisi Warna & 4 & 4 & 8 & $80,00 \%$ & Baik \\
\hline 11 & & Navigasi & 5 & 5 & 10 & $100,00 \%$ & Sangat Baik \\
\hline 12 & & Daya Dukung Musik & 4 & 4 & 8 & $80,00 \%$ & Baik \\
\hline & & Jumlah & 28 & 28 & 56 & \multirow{2}{*}{$93,33 \%$} & \multirow{2}{*}{ Sangat Baik } \\
\hline & & Rata-Rata & 4,7 & 4,7 & 9,33 & & \\
\hline
\end{tabular}

Tabel 6. Skor Penilaian Ujicoba Perorangan Terhadap media video pembelajaran merakit personal komputer Tentang Aspek Kualitas Materi Pembelajaran

\begin{tabular}{|c|c|c|c|c|c|c|c|}
\hline \multirow{2}{*}{ No } & \multirow{2}{*}{ Indikator/Pertanyaan } & \multicolumn{3}{|c|}{ Responden } & \multirow{2}{*}{$\begin{array}{l}\text { Jlh/ } \\
\text { Skor }\end{array}$} & \multirow{2}{*}{ Rata-rata } & \multirow[t]{2}{*}{ Kriteria } \\
\hline & & 1 & 2 & 3 & & & \\
\hline 1 & Kesesuaian Materi & 5 & 4 & 4 & 13 & $86,67 \%$ & Sangat baik \\
\hline 2 & Kejelasan Petunjuk Belajar & 4 & 5 & 5 & 14 & $93,33 \%$ & Sangat baik \\
\hline 3 & $\begin{array}{l}\text { Kemudahan Memahami Kalimat } \\
\text { pada Teks }\end{array}$ & 4 & 5 & 4 & 13 & $86,67 \%$ & Sangat baik \\
\hline 4 & $\begin{array}{l}\text { Kemudahan Memahami } \\
\text { Pembelajaran }\end{array}$ & 5 & 4 & 5 & 14 & $93,33 \%$ & Sangat baik \\
\hline 5 & Ketepatan Urutan Penyajian & 4 & 5 & 4 & 13 & $86,67 \%$ & Sangat baik \\
\hline 6 & Kecukupan Latihan & 5 & 5 & 4 & 14 & $93,33 \%$ & Sangat baik \\
\hline 7 & Kejelasan Umpan Balik & 4 & 5 & 4 & 13 & $86,7 \%$ & Sangat baik \\
\hline 8 & Bantuan Belajar Dengan Program & 4 & 4 & 5 & 13 & $86,7 \%$ & Sangat baik \\
\hline \multicolumn{5}{|c|}{ Rata-rata } & 13,37 & $89,17 \%$ & Sangat baik \\
\hline
\end{tabular}

Tabel 7. Skor Penilaian Ujicoba Perorangan Terhadap media video pembelajaran merakit personal komputer Aspek Kualitas Teknis/Tampilan

\begin{tabular}{|c|c|c|c|c|c|c|c|}
\hline \multirow{2}{*}{ No } & \multirow{2}{*}{ Indikator/Pertanyaan } & \multicolumn{3}{|c|}{ Responden } & \multirow{2}{*}{$\begin{array}{l}\text { Jlh/ } \\
\text { Skor }\end{array}$} & \multirow{2}{*}{ Rata-rata } & \multirow[t]{2}{*}{ Kriteria } \\
\hline & & 1 & 2 & 3 & & & \\
\hline 1 & Keindahan tampilan layar & 5 & 4 & 4 & 13 & $86,67 \%$ & Sangat baik \\
\hline 2 & $\begin{array}{l}\text { Kualiatas video, gambar dan } \\
\text { animasi }\end{array}$ & 4 & 5 & 5 & 14 & $93,33 \%$ & Sangat baik \\
\hline 3 & Komposisi warna & 4 & 5 & 4 & 13 & $86,67 \%$ & Sangat baik \\
\hline 4 & Daya dukung music & 5 & 4 & 5 & 14 & $93,33 \%$ & Sangat baik \\
\hline \multicolumn{5}{|c|}{ Rata-rata } & 13,5 & $90 \%$ & Sangat baik \\
\hline \multicolumn{6}{|c|}{ Total Persentase Skor } & $89,58 \%$ & Sangat baik \\
\hline
\end{tabular}

Berdasarkan uraian dari Tabel 6 dan Tabel 7 dapat disimpulkan bahwa pada uji coba perorangan terhadap media video pembelajaran merakit personal komputer yang dikembangkan menunujukkan bahwa keseluruhan aspek penilaian berada pada kriteria "sangat baik", dengan persentase keseluruhan $89,58 \%$.

Setelah dilakukannya revisi dan perbaikan dari hasil uji coba perorangan terhadap video pembelajaran yang dikembangkan, maka tahap 
selanjutnya adalah melakukan uji coba kelompok kecil. Uji coba kelompok kecil juga dilakukan oleh peserta didik. Uji coba kelompok kecil dilakukan terhadap 9 orang peserta didik yang terdiri dari 2 peserta didik yang berprestasi tinggi, 2 peserta didik berprestasi yang sedang, 5 peserta didik yang berprestasi rendah. Data uji coba kelompok kecil ini dimaksudkan untuk mengetahui beberapa kelemahan atau hambatan yang dihadapi ketika produk media video pembelajaran merakit personal komputer. Data uji coba yang diperolah dari kelompok kecil ini dilakukan untuk mengetahui kembali apa-apa saja kelamahan maupun kekurangankekurangan setelah dilakukannya revisi berdasarkan persepsi peserta didik pada uji coba perorangan sebelumnya terhadap media video pembelajaran merakit personal komputer pada siswa yang telah dikembangkan tersebut. Hasil uji coba kelompok kecil dapat dilihat pada Tabel 8 berikut ini.

Tabel 8. Skor Penilaian Ujicoba Kelompok Kecil Terhadap media video pembelajaran tutorial merakit personal komputer

\begin{tabular}{|c|c|c|c|c|c|c|c|c|c|c|c|c|c|}
\hline \multirow{2}{*}{ No } & \multirow{2}{*}{ Indikator/Pertanyaan } & \multicolumn{9}{|c|}{ Responden } & \multirow{2}{*}{\begin{tabular}{|l|} 
Jlh. \\
Skor
\end{tabular}} & \multirow{2}{*}{ Rata-rata } & \multirow[t]{2}{*}{ Kriteria } \\
\hline & & 1 & 2 & 3 & 4 & 5 & 6 & 7 & 8 & 9 & & & \\
\hline 1 & Kesesuaian Materi & 5 & 4 & 5 & 5 & 5 & 5 & 4 & 4 & 4 & 41 & $91.11 \%$ & Sangat Baik \\
\hline 2 & Kejelasan petunjuk belajar & 4 & 5 & 5 & 4 & 4 & 5 & 5 & 5 & 5 & 42 & $93.33 \%$ & Sangat Baik \\
\hline 3 & $\begin{array}{l}\text { Kemudahan memahami } \\
\text { kalimat pada teks }\end{array}$ & 4 & 5 & 4 & 5 & 5 & 5 & 5 & 5 & 4 & 42 & $93.33 \%$ & Sangat Baik \\
\hline 4 & $\begin{array}{l}\text { Kemudahan memahami } \\
\text { pembelajaran }\end{array}$ & 5 & 4 & 4 & 5 & 5 & 5 & 5 & 5 & 4 & 42 & $93.33 \%$ & Sangat Baik \\
\hline 5 & $\begin{array}{l}\text { Ketepatan urutan } \\
\text { penyajian }\end{array}$ & 5 & 5 & 4 & 4 & 4 & 4 & 5 & 5 & 5 & 41 & $1.11 \%$ & Sangat Baik \\
\hline 6 & Kecukupan latihan & 4 & 4 & 4 & 5 & 5 & 5 & 4 & 5 & 5 & 41 & $91,11 \%$ & Sangat Baik \\
\hline 7 & Kejelasan umpan balik & 5 & 5 & 4 & 4 & 4 & 4 & 5 & 5 & 5 & 41 & $91.11 \%$ & Sangat Baik \\
\hline 8 & $\begin{array}{l}\text { Bantuan belajar dengan } \\
\text { program }\end{array}$ & 4 & 5 & 5 & 5 & 5 & 5 & 4 & 4 & 5 & 42 & $93.33 \%$ & Sangat Baik \\
\hline & Rata- & & & & & & & & & & 41,5 & $92,22 \%$ & Sangat Baik \\
\hline
\end{tabular}

Tabel 4.9. Skor Penilaian Ujicoba Kelompok Kecil Terhadap media video pembelajaran merakit personal komputer Aspek Kualitas Teknis/Tampilan

\begin{tabular}{|l|l|l|l|l|l|l|l|}
\hline \multirow{2}{*}{ No } & \multicolumn{1}{|c|}{ Indikator/Pertanyaan } & \multicolumn{3}{c|}{ Responden } & Jlh/ & \multirow{2}{*}{ Rata-rata } & Kriteria \\
\cline { 3 - 9 } & & 1 & 2 & 3 & Skor & & \\
\hline 1 & Keindahan tampilan layar & 5 & 4 & 4 & 13 & $86,67 \%$ & Sangat baik \\
\hline 2 & $\begin{array}{l}\text { Kualiatas video, gambar dan } \\
\text { animasi }\end{array}$ & 4 & 5 & 5 & 14 & $93,33 \%$ & Sangat baik \\
\hline 3 & Komposisi warna & 4 & 5 & 4 & 13 & $86,67 \%$ & Sangat baik \\
\hline 4 & Daya dukung music & 5 & 4 & 5 & 14 & $93,33 \%$ & Sangat baik \\
\hline \multicolumn{2}{|c}{ Rata-rata } & & 13,5 & $90 \%$ & Sangat baik \\
\hline
\end{tabular}

Setelah diperolah data uji coba kelompok kecil terhadap media video pembelajaran tutorial merakit personal komputer yang dikembangkan, diperoleh kesimpulan bahwa media video pembelajaran yang dikembangkan termasuk dalam kriteria "sangat baik", dengan rata-rata persentase $90 \%$. Berdasarkan hasil yang ditunjukkan pada Tabel 9 di atas, maka dapat diambil kesimpulan bahwa tidak perlu diadakan revisi kembali terhadap media video pembelajaran dan penelitian dapat dilanjutkan ke tahap selanjutnya, yaitu tahap uji coba lapangan terbatas.

Tahap selanjutnya adalah melakukan uji coba lapangan terbatas pada 30 orang guna menghasilkan data-data yang akan dipergunakan untuk mengetahui bagaimana 
manfaat media video pembelajaran merakit personal komputer pada pada pelajaran produktif Teknik Komputer Dan Jaringan bagi pemakainya dan uji coba lapangan menghasilkan data-data yang nantinya akan mengukur efektifitas dari produk yang dikembangkan.

Penilaian yang dilakukan pada uji coba lapangan terbatas terhadap media media video pembelajaran merakit personal komputer pada siswa yang telah dikembangkan secara keseluruhan termasuk dalam kriteria "sangat baik" untuk seluruh indikator penilaian dengan persentase skor total $97,17 \%$. Berikut ini hasil uji coba lapangan terbatas terhadap media video pembelajaran merakit personal komputer pada pelajaran produktif Teknik Komputer Dan Jaringan pada aspek kelayakan tampilan media video pembelajaran tersebut dapat dilihat pada Tabel 10 sebagai berikut:

Tabel 10. Skor Penilaian Ujicoba Lapangan Terbatas Terhadap media video pembelajaran merakit personal komputer

\begin{tabular}{|c|c|c|c|c|c|c|c|c|}
\hline \multirow{2}{*}{ No } & \multirow{2}{*}{ Indikator/Pertanyaan } & \multicolumn{5}{|c|}{ Skor Penilaian } & \multirow{2}{*}{ Rata-rata } & \multirow[t]{2}{*}{ Kriteria } \\
\hline & & 1 & 2 & 3 & 4 & 5 & & \\
\hline 1 & Kesesuaian Materi & - & - & - & 3 & 27 & $98 \%$ & Sangat Baik \\
\hline 2 & Kejelasan petunjuk belajar & - & - & - & 5 & 25 & $96,67 \%$ & Sangat Baik \\
\hline 3 & $\begin{array}{l}\text { Kemudahan memahami } \\
\text { kalimat pada teks }\end{array}$ & - & - & - & 8 & 22 & $94,67 \%$ & Sangat Baik \\
\hline 4 & $\begin{array}{l}\text { Kemudahan memahami } \\
\text { pembelajaran }\end{array}$ & - & - & - & 3 & 27 & $98 \%$ & Sangat Baik \\
\hline 5 & Ketepatan urutan penyajian & - & - & - & 6 & 24 & $96 \%$ & Sangat Baik \\
\hline 6 & Kecukupan latihan & - & - & - & 4 & 26 & $97,33 \%$ & Sangat Baik \\
\hline 7 & Kejelasan umpan balik & - & - & - & 5 & 25 & $96,67 \%$ & Sangat Baik \\
\hline 8 & $\begin{array}{l}\text { Bantuan belajar dengan } \\
\text { program }\end{array}$ & - & - & - & - & 30 & $100 \%$ & Sangat Baik \\
\hline \multicolumn{7}{|c|}{ Rata-rata } & $97,17 \%$ & Sangat Baik \\
\hline
\end{tabular}

Tabel 11. Skor Penilaian Ujicoba Lapangan Terbatas Terhadap media video pembelajaran merakit personal komputer

\begin{tabular}{|c|c|c|c|c|c|c|c|c|}
\hline \multirow[b]{2}{*}{ No } & \multirow{2}{*}{ Indikator/Pertanyaan } & \multicolumn{5}{|c|}{ Skor Penilaian } & \multirow{2}{*}{$\begin{array}{l}\text { Rata- } \\
\text { rata }\end{array}$} & \multirow[t]{2}{*}{ Kriteria } \\
\hline & & 1 & 2 & 3 & 4 & 5 & & \\
\hline 1 & Keindahan tampilan layar & - & - & - & 3 & 27 & $98 \%$ & Sangat baik \\
\hline 2 & $\begin{array}{l}\text { Kualiatas video, gambar dan } \\
\text { animasi }\end{array}$ & - & - & - & 5 & 25 & $96,67 \%$ & Sangat baik \\
\hline 3 & Komposisi warna & - & - & - & 2 & 28 & $98,67 \%$ & Sangat baik \\
\hline 4 & Daya dukung musik & - & - & - & 6 & 24 & $96 \%$ & Sangat baik \\
\hline \multicolumn{7}{|c|}{ Rata-rata } & $97,33 \%$ & Sangat baik \\
\hline
\end{tabular}

Dari Tabel 11 terlihat bahwa hasil uji coba lapangan terbatas pada 30 peserta didik kelas X Teknik Komputer Dan Jaringan secara umum tergolong dalam kriteria "sangat baik" dengan jumlah persentase 96\%. Ini berarti bahwa media media video pembelajaran merakit personal komputer pada siswa kelas $\mathrm{X}$ Teknik Komputer Dan Jaringan yang dikembangkan tidak memiliki masalah maupun kekurangan yang berarti untuk diperbaiki sehingga tidak perlu dilakukan lagi revisi. Dengan demikian, media video pembelajaran merakit personal komputer pada siswa kelas $\mathrm{X}$ Teknik Komputer Dan Jaringan yang dikembangkan telah layak diuji keefektifannya.

Berdasarkan data yang diperoleh dapat diketahui bahwa skor hasil belajar Produktif Teknik Komputer Dan Jaringan pada materi merakit personal komputer dengan menggunakan media video pembelajaran diperoleh skor terendah 78 dan skor tertingi 97 , rata-rata skor 83,66 modus 81,1, median 81,89 dan simpangan baku 5,88 untuk melihat skor peserta didik digunakan kelas interval yaitu 
skor antara frekuensi absolute yaitu jumlah peserta didik yang memiliki skor hasil belajar, dan frekuensi realtif yaitu jumlah persen skor hasil belajar.

Berdasarkan data yang diperoleh dapat diketahui bahwa skor hasil belajar produktif Teknik Komputer Dan Jaringan pada topik merakit personal komputer tanpa menggunakan video pembelajaran merakit personal komputer diperoleh skor terendah 60 dan skor tertinggi 89 , rata-rata skor 69,46 modus 76,81 , median 70,45 dan simpangan baku 5,24. untuk melihat skor peserta didik digunakan kelas interval yaitu skor antar frekuensi absolute yaitu jumlah peserta didik yang memiliki skor hasil belajar, dan frekuensi relatif yaitu jumlah persen skor hasil belajar.

\section{Pengujian Hipotesis}

Hipotesis yang diujikan pada penelitian ini adalah terdapat perbedaan yang signifikan antara hasil belajar peserta didik yang dibelajarkan menggunakan media video dan hasil belajar peserta didik yang tidak menggunakan media video. Pengujian hipotesis yang digunakan adalah uji-T. Dari perhitunganperhitungan diperoleh output $t_{\text {hitung }}$ sebesar 8,77 dan $t_{\text {tabel }}$ sebesar 1,99. Maka diperoleh bahwa $t_{\text {hitung }}>\mathrm{t}_{\text {tabel }}$ atau 8,77 $<1,99$ atau dengan kata lain Ho ditolak dan Ha diterima.

Berdasarkan data-data di atas maka disimpulkan bahwa hasil belajar peserta didik pada mata pelajaran produktif Teknik Komputer dan Jaringan materi merakit personal komputer yang diajarkan menggunakan media video pembelajaran teruji kebenaranya. Hal ini berarti hasil belajar yang menggunakan media video pembelajaran sebesar 83,66 \% lebih tinggi dari peserta didik yang diajarkan tanpa menggunakan media video pembelajaran dengan efektifitas sebesar $69,46 \%$, perhitungan selengkapnya ada pada lampiran.

Kefektifian media video pembelajaran berbasis pendekatan scientific pada pelajaran biologi dengan materi sistem pertahanan tubuh diperoleh dengan cara sebagai berikut :

$\mathrm{X}=\frac{\text { Jumlah Skor yang diperoleh }}{\text { jumlah skor maksimal }} \times 100 \%$

$X=\frac{2928}{3500} \times 100 \%=83,66 \%$

Nilai keefektifan media video pembelajaran berbasis pendekatan scientific ini lebih tinggi dari nilai kefektifan pembelajaran tanpa media video pembelajaran yaitu sebesar $73,06 \%$ yang diuraikan sebagai berikut :

$\mathrm{X}=\frac{\text { Jumlah Skor yang diperoleh }}{\text { jumlah skor maksimal }} \times 100 \%$

$X=\frac{2431}{3500} \times 100 \%=69,46 \%$

Hal ini berarti hasil belajar peserta didik yang menggunakan media video pembelajaran dengan materi merakit personal komputer lebih tinggi dari hasil belajar peserta didik yang diajar tanpa menggunakan media video pembelajaran pada pelajaran merakit personal komputer sebesar $83,66 \%$ perhitungan selengkapnya pada lampiran. Adapun rangkuman dari hasil uji coba hipotesis II yakni mengenai keefektifan media video pembelajaran rias karakter ini dapat dilihat pada Tabel berikut :

Tabel 12 . Hasil Uji Coba Keefektifan Media Rias Karakter

\begin{tabular}{|c|c|c|}
\hline \multicolumn{2}{|c|}{ Pengujian Media } & \multirow{2}{*}{ Keterangan } \\
\cline { 1 - 2 } Kelas Eksperimen & Kelas Kontrol & Hipotesis diterima \\
\hline $83,66 \%$ & $69,46 \%$ & Hete
\end{tabular}

Berdasarkan tahapan uji keefektifan produk media video pembelajaran yang telah dipaparkan, maka dapat disimpulkan bahwa media video pembelajaran yang dikembangkan efektif untuk meningkatkan hasil belajar pada materi merakit personal komputer.

Pembahasan

Pengembangan media video pembelajaran merakit personal komputer dilakukan berdasarkan tahapan sebagaimana yang terdapat dalam prosedur. Hasil pengembangan selanjutnya dilakukan uji kelayakan atau validasi oleh ahli yang telah ditentukan. Berdasarkan hasil validasi yang dilakukan, produk media video pembelajaran merakit personal komputer dinyatakan layak untuk diteruskan dalam uji coba lapangan. Media video pembelajaran merakit personal komputer yang dikembangkan telah memenuhi standar berdasarkan perancangan standar pengembangan media video pembelajaran dan standar materi pembelajaran.

Penelitian pengembangan produk yang dilakukan ini diarahkan untuk menghasilkan suatu produk berupa media video pembelajaran merakit personal komputer yang digunakan 
untuk meningkatkan proses pembelajaran maupun kompetensi peserta didik.

Aspek yang direvisi dan disempurnakan berdasarkan analisis data dan uji coba serta masukan dari ahli materi, ahli desain pembelajaran, ahli media video pembelajaran ini. Hal ini bertujuan untuk menggali beberapa aspek yang lazim dalam proses pengembangan suatu produk. Variable-variabel media video pembelajarn yang dinilai meliputi kelayakan isi, penyajian, kegrafikan, keaktifan, kebahasaan, pemograman, tampilan dan pemanfaatan.

Pada hasil angket yang disampaikan kepada ahli media video pembelajaran memberikan tanggapan $92,67 \%$ bahwa media video pembelajaran layak digunakan karena telah memenuhi prinsip-prinsip dan criteria pengembangan media video pembelajaran. Sementara itu, ahli desain pembelajaran memberikan tanggapan 93,53\% bahwa media video pembelajaran merakit personal komputer layak digunakan karena telah didesain sedemikian rupa dan memenuhi standar desain pembelajaran. Ahli materi pembelajaran member tanggapan $92,27 \%$ bahwa media video pembelajaranmerakit personal komputer layak digunakan karena telah memuat materi dan criteria penyampaian yang memenuhi syarat penyampaian pesan kepada peserta didik. Berdasarkan analisis hasil nilai rata-rata produktif Teknik Komputer Dan Jaringan yang diajarkan menggunakan media video pembelajaran merakit personal komputer sebesar $83,66 \%$, sedangkan hasil nilai rata-rata mata pelajaran produktif Teknik Komputer Dan Jaringan $69,46 \%$. Dengan melihat pedoman dan kriteria penilaian menurut Sugiono (2010 : 257) maka dapat disimpulkan data diatas membuktikan bahwa penggunaan media video pembelajaran merakit personal komputer lebih efektif dalam meningkatkan kompetensi dan pengetahuan peserta didik pada mata pelajaran produktif Teknik Komputer Dan Jaringan pada materi merakit personal komputer.

Beberapa kegunaan dan manfaat dalam penggunaan media video pembelajaran media video pembelajaran merakit personal komputer sebagai berikut: (1) materi dapat menyelesaikan permasalahan karena konsep yang direncanakan untuk mempermudah peserta didik dan sistematis, (2) media video pembelajaran merakit personal komputer memberi kesempatan kepada peserta didik untuk belajar sesuai dengan daya pikir masing-masing individu, (3) belajar lebih cepat dan menarik sehingga tidak menimbulkan kebosanan, (4) media video pembelajaran berbasis tutorial merakit personal komputer ini juga dapat digunakan sebagai alternative media video pembelajaran secara konvensional maupun individu, mengatasi jarak dan waktu, mampu menggambarkan kemudahan dengan menggunakan video tutorial pada pembelajaran, dapat diulang-ulang bila perlu untuk menambah kejelasan, pesan yang disampaikannya cepat dan mudah diingat, dan mampu berperan sebagai media utama untuk memecahkan masalah yang akan disaksikan di dalam kelas..

Berdasarkan hasil validasri yang dilakukan, produk media video pembelajaran merakit personal komputer dinyatakan layak untuk diteruskan dalam uji coba lapangan. Media video pembelajaran yang dikembangkan telah memenuhi standar berdasarkan perancangan standar pengembangan media video pembelajaran dan standar materi pembelajaran hal ini dapat terlihat pada Tabel 13 di bawah ini :

Tabel 13. Rangkuman Hasil Kelayakan Produk Berdasarkan Ahli Materi, Ahli Desain, Ahli Media Pembelajaran

\begin{tabular}{|l|l|l|}
\hline Ahli Validasi & Hasil Persentase & Layak / Tidak Layak \\
\hline Ahli Materi Pembelajaran & $92,27 \%$ & Layak digunakan \\
\hline Ahli media Pembelajaran & $92,67 \%$ & Layak digunakan \\
\hline Ahli desain Pembelajaran & $93,53 \%$ & Layak digunakan \\
\hline
\end{tabular}

Pada hasil angket yang disampaikan kepada ahli media video pembelajaran memberikan tanggapan $92,67 \%$ bahwa media video pembelajaran layak digunakan karena telah memenuhi prinsip-prinsip dan criteria pengembangan media video pembelajaran.
Sementara itu, ahli desain pembelajaran memberikan tanggapan $93,53 \%$ bahwa media video pembelajaran merakit personal komputer layak digunakan karena telah didesain sedemikian rupa dan memenuhi standar desain pembelajaran. Ahli materi pembelajaran 
memberikan tanggapan $92,27 \%$ bahwa media video pembelajaran pembelajaran tutorial merakit personal komputer layak digunakan karena telah memuat materi dan criteria penyampaian yang memenuhi syarat penyampaian pesan kepada peserta didik.

Dari hasil pengolahan data penelitian yang dilakukan, terdapat rata-rata hasil belajar produktif Teknik Komputer Dan Jaringan yang dibelajarkan menggunakan media video pembelajaran merakit personal komputer sebesar 83,66\%. Sedangkah hasil belajar produtf Teknik Komputer Dan Jaringan materi merakit personal komputer diajarkan tanpa menggunakan media video pembelajaran sebesar $69,46 \%$. Dari data ini membuktikan bahwa media video pembelajaran merakit personal komputer ini layak dan efektif digunakan dalam meningkatkan kompetensi dan pengetahuan peserta didik.

Penggunaan media video pembelajaran merakit personal komputer memungkinkan peserta didik untuk lebih mudah memahami langkah-langkah merakit komputer karena dari media video pembelajaran ini memungkinkan peserta didik untuk berinteraksi langsung, memiliki susunan tahapan pembelajarang yang lebih teratur dan lebih jelas, sehingga setiap peserta didik tidak kesulitan lagi dalam memecahkan masalah. Selain itu media video pembelajaran ini sangat praktis, karena media ini dapat dibawa peserta didik dan dipelajari di rumah.

Berdasarkan hasil temuan yang telah diuraikan pada kesimpulan dan impilkasi hasil penelitian, berikut ini diajukan beberapa saran yaitu:

1. Pembelajaran dengan menggunakan video tutorial merakit personal komputer merupakan syarat salah satu yang harus dikuasai seorang guru dalam mengimplementasi kurikulum 2013 sesuai yang dianjurkan pemerintah, maka sebaiknya para guru terutama guru di sumatera utara supaya mendalami pembelajaran dengan menggunakan video tutorial serta pada setiap mata pelajaran agar melengkapi keperluan fasilitas seperti ruang praktek yang memadai, perlengkapan dan peralatan praktek serta sumber-sumber yang diperlukan sehingga dapat mengembangkan kreatifitas peserta didik.
2. Media video pembelajaran ini adalah salah satu alat untuk membantu dalam proses penyampaian pembelajaran, keberadaan guru serta kemampuan guru dalam menggunakan media video pembelajaran sangat diperlukan sebagai fasilitator sehingga peserta didik dapat terlibat aktif dalam proses pembelajaran.

3. Agar hasil produk lebih maksimal dan layak digunakan lebih jauh lagi, maka diperlukan hal-hal yang mendukung pengembangan produk yang terdiri dari : ahli pembelajaran, ahli bidang studi dan ahli materi professional, ahli media video, dukungan dan prasarana serta waktu yang tersedia.

4. Dengan alasan keterbatasan waktu bagi peneliti, sehingga masih banyak beberapa pengaruh-pengaruh yang belum terkontrol, maka perlu kiranya dilakukan penelitian lebih lanjut pada sampel yang lebih representatif.

\section{DAFTAR PUSTAKA}

AECT. (1977). Definisi Teknologi Pendidikan (satuan tugas definisi \& terminology $A E C T$ ). Jakarta : Rajawali

Abdullah, dkk. (2013). Teknologi Pendidikan. Bandung : Rosda Karya.

Abdurrahman. Mulyono, (1999). Pendidikan Bagi Anak Berkesulitan Belajar, Jakarta: Rineka Cipta.

Anderson, R. H. (1983). Pemilihan dan Pengembangan Media Untuk Pembelajaran. Jakarta: Universitas Terbuka

Arikunto, Suharsimi. (2015). Dasar-Dasar Evaluasi Pendidikan, Jakarta : Bumi Aksara.

Arikunto, S. (1999). Prosedur Penelitian. Jakarta: Rineka Cipta.

Arsyad, Azhar. (2014) . Media Pembelajaran (Edisi Revisi). Jakarta : PT Raja Grafindo Persada.

Ary, D., Jacobs, L.C Razavieh, A. (1982). Pengantar Penelitian Dalam Pendidikan. (Penerjemah Furcham, A). Surabaya : Usaha Nasional.

Baskara, Agung. (2015). Jurus Rahasia Merakit Komputer Tanpa Guru. Jakarta : KIR Direction.

Bloom, Benjamin S. (1977). Taxonomy of Educational Objektif, Hand Book I, 
Cognitif Domain. New York : Longman Inc.

Borg,W.R \& M.D.Gall. (1983). Educational Research : An Introduction, New York : Longman, Inc.

Bretz, Rudi. A. (1971). Taxonomy of Communication Media, Educational Technology publications. Englewood clifft, New Jersey.

Dick, Walter, etc. (2001). The Systematic Design of Instruction. Fifth Edition.Wesley Educational Publishers Inc..

Danim, Sudarwan. (2010). Media Komunikasi Pendidikan. Jakarta: Bumi Aksara

Daryanto. (2010). Media Pembelajaran Perannya Sangat Penting dalam Mencapai Tujuan Pembelajaran. Yogyakarta : Gava Media.

Dermawan, Deni. (2011). Teknologi Pembelajaran. Bandung : Remaja Rosdakarya.

Dimyati \& Mujiono. (2009). Belajar \& Pembelajaran. Jakarta : Rineka Cipta.

Dick, Walter, etc. (2001). The Systematic Design of Instruction. Fifth Edition. Wesley Educational Publishers Inc.

Fajar, Malik A. (2014). Perbandingan Sistem Pendidikan 15 Negara. Bandung : Lubuk Agung

Hamid, Abdul. (2014). Teori Belajar dan Pembelajaran. Medan : Progam Pascasarjana Universitas Negeri Medan.

Kustandi, Cecep dkk. (2013). Media Pembelajaran. Bogor: Ghalia Indonesia.

Uno, Hamzah, dkk. (2014). Variabel Penelitian dalam Pendidikan dan Pembelajaran. : Jakarta : PT.Ina Publikatama.

. (2004). Model Pembelajaran. : Gorontalo : Nurul Jannah.

Hujair, AH. Sanaky. (2009) .Media Pembelajaran. Yogyakarta : Safiria Insani Press

Hamalik, Oemar. (2005). Proses Belajar Mengajar, Bandung : Bumi Aksara.
Hamalik, Oemar. (2003). Kurikulum Dan Pembelajaran. Jakarta : Bumi Aksara.

Miarso, Yusufhadi. (2004). Menyemai Benih Teknologi Pendidikan. Jakarta: Prenada Media dan Pustekkom Diknas.

Munadi, Yudhi. (2013). Media Pembelajaran. Jakarta : Referensi (GP Press Group )

Musfiqon, HM. (2012). Pengembangan Media dan Sumber Pembelajaran. Jakarta : Prestasi Pustaka Karya.

Nurhadi, Wahyudi. (2003). Media Pembelajaran.Jakarta : Gama Persada.

Panjaitan, Keysar. (2010). Merancang Butir Soal dan Instrument untuk Penelitian. Gorontalo : Nurul Jannah.

(2009). Pendidikan Masa Depan, Gorontalo : Nurul Jannah.

(2014). Pengantar Belajar dan Pembelajaran. Gorontalo : Nurul Jannah.

Sadiman, Arif dkk. (2002). Media Pendidikan : Pengertian, Pengembangan dan Pemanfaatannya. Jakarta: Raja Grafindo Persada.

Sudjana. (2001). Evaluasi Hasil Belajar. Bandung, Sinar Baru.

Suparman, Atwi. (2011). Desain Intruksional Modern. Jakarta :Penerbit Erlangga

Susilana, Rudi dkk. (2008). Media Pembelajaran . Bandung : CV.Wacana Prima.

Srililis. (2008). Pengembangan Inovasi Pembelajaran Mandiri. Bandung : Lubuk Agung.

Smaldino, S.E dkk. (2008). Instructional Technology and Media For Learning. Jakarta : Kencana Prenada Media Group.

Trianto. (2009). Mendesain Model Pembelajaran Inovatif Progresif. Jakarta: Prenada Media Group

Usman, dkk. (2006). Pengantar Statistika (Edisi Kedua), Jakarta: Bumi Aksara.

Warsita, B. (2002). Teknologi Pembelajaran Landasan \& Aplikasinya. Jakarta : Rineka Cipta. 